\title{
Investigating the Petition of Marshall Islands against Britain in the International Court of Justice
}

\author{
Sahar Asadi Moghadam ${ }^{1} \&$ Abu Mohammad Asgar Khani ${ }^{2}$ \\ ${ }^{1}$ Department of Human Sciences, Qeshm International Branch, Islamic Azad University, Tehran, Iran \\ ${ }^{2}$ Ph.D. International Relations, Queen's University at Kingston, Ontario, Canada \\ Correspondence: Sahar Asadi Moghadam, Department of Human Sciences, Qeshm International Branch, Islamic \\ Azad University, Tehran, Iran. E-mail: saharasadimoghaddam@gmail.com
}

\author{
Received: April 22, 2017 \\ Accepted: May 7, $2017 \quad$ Online Published: July 18, 2017 \\ doi:10.5539/jpl.v10n4p15 \\ URL: https://doi.org/10.5539/jpl.v10n4p15
}

\begin{abstract}
The international court of justice was established by Charter of the United Nations and is considered as one of its integral parts in which only experienced and knowledgeable judges and lawyers can be employed. In fact, it consists of several independent judicial institutions. Marshall Islands, a country which was cruelly imposed to nuclear tests, was brave enough to sue powerful countries with nuclear weapons. In 1996, nuclear weapons case was considered by the international court of justice for the first time. All the court's members came to this conclusion that these countries should stop their nuclear activities and they are not permitted to use any nuclear weapon. As a result they ratified a bill. Then, Marshall Islands' petition was considered by the international court of justice in The Hague. This country also took legal action against U.S.A. and the federal judiciary of the United States accepted to take it into consideration. This paper aims at analyzing the petition of Marshall Islands against Britain in the international court of justice. According to the content of this petition, countries can't develop their nuclear weapons which threat men and the world. As a result, the destruction of present nuclear weapons is the only effective way to achieve this goal.
\end{abstract}

Keywords: the international court of justice, petition, Marshall islands' petition, nuclear weapons

\section{Introduction}

Analyzing the role of International law in inhibiting countries from developing their nuclear weapons is considered very important especially when a country decides to take legal actions against these threats (R. Beldscoe and B. Boczek, the International Law Dictionary, Oxford, Clio PressLtd, 1987). Those who believe that it is not legal to use nuclear weapons believe that this inhibition can be in form of using force by countries to enforce the law in international relations. This form of legal action is defined by the charter of the United Nations, Environmental law, Human rights, and international human right or armed conflict law. However, the international court of justice came to this conclusion that some of the sources of law are not related to this issue. These groups who think that usage of nuclear weapons is illegal believe that any use of these weapons can threat human right and increase fatality. In other words, according to the article 6 of International civil and political rights, using nuclear weapons threats human life and right. On the other hand, the opponents of this article claim that nothing is mentioned about these weapons in this article. However, the international court of justice believes that the principles of international law such as article 6 that inhibits countries from using nuclear weapons can put into action even during war. Therefore according to article 4, they are not permitted to threat human rights even under specific conditions. Marshall Islands, the country which imposed to nuclear tests in a cruel way was brave enough to sue powerful countries which have nuclear weapons. In 1996, the international court of justice (ICJ) considered nuclear weapons case for the first time. All the court's members came to this conclusion that these countries should stop their nuclear activities and they are not permitted to use any nuclear weapon. As a result they ratified a bill. Then the international court of justice in The Hague took Marshall Islands petition into consideration. This country also took legal actions against U.S.A. and the federal judiciary of the United States accepted to take it into consideration.

\subsection{The Definition \& Structure of International Court of Justice}

In the late $19^{\text {th }}$ century, the international court of justice was established. It consisted of qualified individuals who 
were always ready to take countries legal petitions into consideration. In Hague Conventions of 1899 and 1907, a specific legal system was designed for international court of justice. However, this legal action had no effect on the results of first international wars (1914-1918) (Mosazadeh, 2004). In 1945 and according to the decision of the United Nations Conference on International Organization, the international court of justice was established as the fundamental and inseparable part of the United Nations (Ganji, 1971). Unlike the traditional international court of justice, this court was located in the United Nations institute. The international court of justice established by the charter of the United Nations is considered as an integral part of this institution. It is one of the fundamental parts of the United Nations that it consists of independent judicial institutions and experienced judges and lawyers according to the article 14 of the charter of the United Nations.

Based on the article 9 of the United Nations Security Council and Public international law, the process of selecting judges and lawyers follows two criteria:

1) They should be epistemologically qualified. It is important for them to have important jobs and highest judicial capacities or be one of the lawyers or experienced members of the International law (Article $2 \& 3$ of the international court of justice).

2) The court should consist of judges both as the representatives of important civilizations and representatives of important legal systems (civil law) of the world (Ibid, article 9).

The judges shouldn't have any other job; therefore they can't cooperate in any form of political or administrative action (Ibid, article 16).

In order to avoid imposing political pressures on judges in courts, their dismissal is not allowed unless other judges came to this conclusion that he/she is not qualified enough for this position (Ibid, article 18). At least 9 judges should be present in court's conferences (Ibid, B). Also there is no difference between the permanent and temporary members of the Security Council and both groups can engage in the process of selecting judges of courts (The directory of the united nations 3, 1995). All judges should avoid any kind of political or administrative mission. As a representative, legal adviser, or lawyer of one of the parties or as a member of national court of justice or international court of justice, or members of the jury, they cannot involve themselves in legal disputes (Article 17 of the international court of justice). Countries that want to take legal actions against illegal activities of other countries first decide which court is qualified enough to take the petitions into consideration because it is not possible to give judgment about legal actions of international court of justice without government permission. Therefore, government agreement is considered as main and prior requirement of disputes settlement. Also according to the article 165, this court is allowed to issue "advisory opinion" based on the decisions of the organizations and institutions of the United Nations charter.

\subsection{Definition of Petition and Its Different Forms}

"Petition" is considered as the shortened form of Petitioning. Petitioning can also be defined as "litigation/advocacy of justice". It is defined as a petition paper that is written by the petitioner. Then the court can take it into consideration. It also has the meaning of "complaint" (Moein, 2001). According to the principles of the international court of justice, this court can take legal petitions into consideration only when it receives the petition". Therefore, the court can take legal actions only when the petitioner asks for justice. In terms of idiomatic expressions, "petition" refers to the first and the most important note of each legal case that is written on specific printed notes. The court's judge takes it into consideration and makes decisions based on the type of petition (Vahedi,. 1999).

Legal petitions have different forms predicted in civil procedure law:

1) First pleading \& complaint: First pleading is a document through which the petitioner issues his/her petition paper to the court. The content of a petition should be based on the principles of the international court of justice. This petition is issued in case of asking for justice, revision, appeal, adjudication, and third party's complaint.

2) Original \& incidental petition: Original petition is a document through which the first petition or complaint is established. Therefore, not only the first petition but also cases such as asking for justice and revision can be considered as original petitions. Every petition then is sent to the court. It can be considered an incidental petition only if it is correlated with the original complaint.

3) Written, Verbal and Telegraphic petition: The written and verbal forms of petition can be used in article 503 of the civil procedure law though articles 49 and 51 of the civil procedure law emphasize on the written form of petitions. Therefore it is acceptable that the petition should be issued in written form. Telegraphic petition was predicted in article 71 of the ancient law. As a result, in urgent cases, the petitioner uses telegraphic petition. However no article has been defined in the new civil procedure law that emphasizes on the use of this form of 
petition. Therefore when the printed petition note is not available, lawmaker can't make decisions about the petitioners' complaints (Ibid, p.15).

\subsection{The Petition of Marshall Islands}

In April 2014, Marshall Islands country issued a petition note to the international court of justice against the 9 powerful countries with nuclear weapons. That time this country claimed that the mentioned countries were not allowed to use nuclear weapons because the ICJ inhibited these nine countries including U.S.A. , England, France, Russia, China, Pakistan, and like from using these weapons. Marshall Islands has divided these countries into two groups: Those which according to the second paragraph of the article 36 of the compulsory jurisdiction of the ICJ accepted this principle (Britain, India, and Pakistan) and those which didn't accept it (U.S.A, France, China, Israel, and North Korea). According to this fact that Britain, India, and Pakistan have already accepted this principle, the petitions which were issued to the international court of justice against these countries are available in the public list of this court. But according to the fifth paragraph of the article 38 of the court of justice, the petitions which were issued against other countries that didn't accept this principle was not recorded in the public list of the court of justice. However if the court takes this complaint into consideration, it can be recorded in the mentioned list. As a result, the registry records of Supreme Court informed these countries about the petition of Marshall Islands (Kamalinezhad et al., 2014).

Tony Brum, the prime minister of Marshall Islands country has noted that:

"Our people have experienced the inevitable and destructive effects of using nuclear weapons. Therefore, we decided to assure people that these destructive events will not happen again. These weapons should be destroyed because they threat people all over the world".

All petitions that have been issued to the international court of justice can be mentioned as:

1) Violation of honesty and good will and discontinuance of the development of nuclear weapons by rejecting multi-dimensional negotiations or following policies that formed against discontinuance of the development of nuclear weapons.

2) Violation of honesty and good will in negotiations in order to inhibit countries from using nuclear weapons as soon as possible. It is because in some countries these weapons are used in order to modernize nuclear powers and in some other countries like Pakistan and India, these weapons have developed.

3) Violation of honesty and good will through preserving nuclear power stations.

4) Violation of nuclear weapons development discontinuance and on the other hand, discontinuance of nuclear weapons development by members of international law with the permission of Tony Brum (Prime minister of the Marshall Islands) and Fon Van Bisen (A lawyer in Amsterdam and one of the members of IALANA), Lori Ashton, Klair Roherberk (U.S.A.), Nicholas Grief (A teacher who is experienced in the field of international law and is one of well-known teachers in economic and political law university in London), John Burroughs (The administrative manager of the law committee of nuclear politics in the Ialana department of the United Nations), David Krueger ( The chief executive in the Nuclear Age Peace Foundation in California), Petroice (The joint chief of IALANA).

\section{Literature Review of Marshall Islands' Legal Case}

At the beginning of the cold war (1946-1958), the United States performed 67 nuclear tests in Marshall Islands. In general, these tests are known as Castle Bravo (Defined as Operation castle) (Islanders Want the Truth about Bikini Nuclear Test" Japanfocus.org. July 4, 2010). "The total weight of nuclear bombs was 108/496 kt. They were 7/200 times stronger than nuclear weapons which were used in world war II (The History of the RMI's Bilateral Relationship with the United States). In 1956, the atomic energy commission introduced Marshall Islands as the most polluted country of the world which was polluted due to Hydrogen Bomb test. Marshall Islands used two independent judicial processes in order to issue its petitions to the international court of justice: National \& International petitions.

1) National petition of Marshall Islands emphasized on the role of America in violating international commitments regarding discontinuance of the development of nuclear weapons. This country issued its petition or complaint note to the federal judiciary of the United States against U.S.A. government. In this note, besides the violation of the principles of international law regarding the discontinuance of the development of nuclear weapons, the record of nuclear tests in Marshall Islands was considered. It is unlikely that this court has taken legal actions against U.S.A. government. On the other hand, Marshall Islands also didn't expect it and it only wanted to inform people all over the world that nuclear tests of America have killed thousands of Marshall 
Islands' citizens and had negative effects on the natural environment of the country.

2) The international petition of the international court of justice is the most important international judicial section, because this court is known as the global court and it is considered as one of the six main organs of the United Nations. In fact, the district court of The Hague is considered as the main judicial part of the United Nations which follows the principles of the Security Council and general assembly. Therefore even if this legal complaint fails, it affects peoples' minds due to having international psychological and political effects (Cooke, S. 2009). These legal actions (Issuing petition notes against U.S.A. by Marshall Islands country) and the destructive effects of nuclear bombs and weapons have not finished yet (Cooke, S. 2009).

In 2012 (April 24), Marshall Islands (RMI) issued a petition note to the international court of justice against nuclear countries. According to the content of this complaint paper, nuclear countries have violated the principles regarding the discontinuance of nuclear weapons. Therefore Marshall Islands expect the court to make serious decisions about the nuclear activities of the mentioned countries as soon as possible (One year). However, ICJ has considered a short term scheduler regarding England and India countries. India has issued a letter to the international court of justice and claimed that the court is not qualified enough to take legal actions. Therefore, it didn't select any representative and didn't attend RMI \& India conference.

As a result, ICJ ordered to record RMI bill regarding the qualification of the court till 2016 (December 16) and the other bill by India till 2015 (June 16). RMI \& Pakistan conference was scheduled to be held on $9^{\text {th }}$ July and the scheduled time to record RMI bill was $16^{\text {th }}$ March (2015) and for England bill was $16^{\text {th }}$ December (2015). Among these 9 nuclear countries, only 3 countries accepted that the international court of justice is qualified enough to take legal actions. These countries were England, India, and Pakistan. The other six countries were forced to accept this principle. Therefore, they fulfilled the principles of the international law and finally discontinued the development of nuclear weapons. In these 9 petitions, the truth about the nuclear equipment, policies of the country and restrictions of legal actions were considered. On the other hand, updating and modernizing processes of nuclear equipment inhibit the countries from discontinuing nuclear activities as soon as possible. It indicates that the country is not qualified enough to fulfill the principles of the international law. According to RMI, the negligence of most nuclear countries from the beginning of the negotiations was somehow related to the principle of discontinuing nuclear activities. Also the refusal of these countries to cooperate in working groups indicates that they violated the legal principles.

RMI expects the international court of justice to analyze the function of these countries in fulfilling the principles of NPT, VI, and ICJ.

\subsection{Nuclear Tests and Their Effects on the Citizens of Marshall Islands}

Although six decades have passed, the citizens of Marshall Islands which is located in Pacific ocean still suffer from serious diseases resulted from U.S.A. nuclear tests performed in this Island. American nuclear scholars performed 67 nuclear and hydrogen tests in the waters of this island (40s \& 50s). Now, the destructive effects of these tests have changed the citizens' lives in a negative way and although six decades have passed, they still suffer from serious diseases resulted from nuclear tests. $90 \%$ of Rongelap's citizens that were under 12 years old suffer from Thyroid cancer when the nuclear explosion occurred. Also, the crews of a Japanese fishing vessel known as "Focoryo Maro" were killed two hours after the explosion. The national cancer institute also announced that the rate of cancer diseases has increased by 9 percent in this island due to the nuclear tests of America and nuclear explosion.

Peters et al (2013) examined the distribution of cesium-137 in tree products collected from residence islands impacted by the U.S. nuclear test program in the northern Marshall Islands. They reported High levels of variability across all islands and results of their study will allow atoll communities to make informed decisions about resettlement and possible options for cleanup and rehabilitation of islands and atolls.

Gerrard (2015) in an study entieled "America's Forgotten Nuclear Waste Dump in the Pacific " aimed to shed light on the environmental and security challenges of nuclear waste disposal in the Pacific and beyond using the experience of the Marshall Islands as a case study.

Ahlgren et al (2014) argued that dependence on food aid has gradually increased over the past 70 years in the Marshall Islands, starting with population relocation because of war and nuclear testing and most recently because of climate change. They believed that the health impacts of the supplemental imported diet, combined with migration to population centers, may result in an even greater prevalence of chronic diseases, and exert pressures that lead to more communicable disease, further exacerbating the syndemics in the Marshall Islands. Accordingly, donors and the government should re-examine the content of food aid and ensure it is of sufficient 
quality to meet the right to health obligations.

\section{The Results of the Statement about Nuclear Weapons (International Court of Justice)}

1) According to both moral and legal dimensions of this statement, the most important thing is that all the mentioned countries should follow the legal principles that were issued based on the international law through pacta suntservanda. In the provision of nuclear weapons (1968) which is now referred to as NPT provision, it has been mentioned that non-nuclear countries are not allowed to use nuclear weapons and nuclear countries should take legal actions regarding the discontinuance of the nuclear weapons development.

2) This provision emphasizes on the violation of legal principles mentioned in fourth paragraph of NPT provision and international law by countries. It specially focuses on the avoidance of NPT governments from fulfilling legal actions. In fourth paragraph of this provision, the international court of justice has emphasized on the countries good will and negotiations about the process of discontinuing the development of nuclear weapons and the efficient control of the international court of justice.

3) The international court of justice has also mentioned that nobody can underestimate the destructive power of nuclear weapons and the fact they can destroy all the creatures.

4) Some nations that have the most powerful military equipment and force decide to use nuclear weapons in order to guarantee the safety of their citizens even if their nuclear activities destroy other countries. It other words they follow the nuclear policies in order to develop their nuclear weapons.

5) Considering the principles and criteria of the international law, ICJ decided to take legal actions against illegal actions of Britain government which is one of the NPT provisions countries. The declarations of this court is mentioned in details: Britain: (A) has violated the principles mentioned in the fourth paragraph of NPT provision in a consistent way including its provisions toward efficient negotiations regarding the discontinuance of the nuclear weapons development as soon as possible. Note that all the negotiations are under the control of the international court of justice. (B) It has violated the principles of the ordinary international law. (C) It has violated the provisions regarding fulfillment of the principles of the international law.

6) In this statement, the Marshall Islands is considered as the petitioner (Marshall Islands, RMI, or the petitioner country). The petitioner is classified as a non-nuclear country in NPT provision. In 1995 ( $30^{\text {th }}$ January), this country was considered as a party to the provision.

7) According to the attempts in forming a strategy in order to change weather condition, RMI, one of the members of the NPT provision, came to this conclusion that it is not acceptable that NPT countries violate the principles mentioned in the fourth paragraph of the provision and principles of the ordinary international law. As a result this provision aims at guaranteeing the fulfillment of the legal provisions of NPT that were disregarded by Britain government about 44 years ago.

8) One of the reasons that RMI became one of the members of NPT or a party to the provision is that NPT provision plays an important role in the international law and it has the capacity to inhibit countries from developing nuclear weapons. NPT provision consists of the serious and legal commitment of nuclear countries to negotiate about the process of discontinuing nuclear weapons. Unfortunately, they have violated these principles.

9) According to the content of this provision, each party engages in negotiations in an efficient manner in order to take legal actions regarding the discontinuance of nuclear activities as soon as possible. Note that the international court of justice controls these actions in an efficient manner.

10) In 1996 ( $8^{\text {th }}$ July), the members of the international court of justice came to this conclusion that it is necessary to control the legal actions of the countries in the process of discontinuing nuclear activities.

11) These provisions are not limited to NPT countries. In other words according to the principles of the international law, all the countries can be a member of this provision.

\section{Conclusion}

In 1986, Marshall Islands and U.S.A. concluded the nuclear free zone treaty. Therefore in 1990 (December 22), all the nuclear activities of U.S.A. in Marshall Islands were stopped. Now, RMI consists of 30 provinces. This country has issued a remarkable petition against the United States and other eight countries which use weapon of mass destruction. As a result, these countries were committed to follow the principles regarding the discontinuance of the nuclear weapons development (NPT). In 1970, the international court of justice took these provisions into consideration in order to assure Marshall Islands that nuclear countries were not allowed to use or develop nuclear weapons. Now, 46 years has passed but these countries haven't discontinued the development of nuclear weapons yet. More than 17000 nuclear weapon have been built and made this world a dangerous place 
for living because nuclear activities can threat human life. The citizens of Marshall Islands have experienced destructive effects of nuclear activities. The nuclear age peace foundation (NAPF) has supported the legal action of Marshall Islands and guided this country in achieving its goal. NAPF has the same opinion and it believes that the only way of guaranteeing the safety of people all over the world is destroying all the nuclear weapons. It is not related to the matter of nationalism or chauvinism. It somehow aims at saving peoples' lives. Most of world political leaders believe that the nuclear power stations should be destroyed and every country which builds nuclear bombs is an anti-humanity country. As Desmond Tutu, the retired Anglican bishop who received the Nobel Peace Prize in 1984 says, "The violation of these countries in following the principles of the international law has increased the possibility and danger of destruction. It can be considered as one of the fundamental moral and legal issues of our time. As a result, discontinuing nuclear activities is the only way of protecting people all throughout the world. Also destruction of all the nuclear weapons can be considered as the only way of realizing this goal.

\section{Recommendations}

The international court of law can issue specific principles in order to inhibit all the countries from performing nuclear tests or using nuclear weapons.

The best way of reaching this goal is that ICJ uses neutralism (policy) and takes legal cases such as the petition of Marshall Islands into consideration independent from international powers.

\section{References}

"The Directory of the United Nations 3", The Subsidiary Organs, the International Court of Justice \& Their Relationship with Islamic Republic of Iran, The Department of Political \& International Studies, pp. 552-553.

Ahlgren, I., Yamada, S., \& Wong, A. (2014). Rising oceans, climate change, food aid, and human rights in the Marshall Islands. Health Hum Rights, 16(2), E69-81.

Ganji, M. (1971). The Theories of the United Nations (Vol. 1, 1st ed.). Pocketbook joint stock company press with the assistance of Franklin press, pp.353-354.

Gerrard, M. B. (2015). America's Forgotten Nuclear Waste Dump in the Pacific. SAIS Review of International Affairs, 35(1), 87-97. https://doi.org/10.1353/sais.2015.0013

Islanders Want the Truth about Bikini Nuclear Test. (210). Japanfocus.org. RetrievedJuly 4.

Kamalinezhad, H et al. (2014). Latest News about the United Nations, Two journals of the Iranian Operations Research Society of the United Nations, second year, No. 35, pp. 4-5.

Moein, M. (2001). The Persian-Persian Dictionary (Vol. 2, 18th ed.). Tehran, Amirkabir press, p. 1478.

Mosazadeh, R. (2004). The Concept of Public International Law. Tehran, Mizan press, p. 46.

Peters, S. K. G., Kehl, S. R., Martinelli, R. E., Tamblin, M. W., \& Hamilton, T. F. (2013). Distribution of cesium-137 in tree crop products collected from residence islands impacted by the US nuclear test program in the northern Marshall Islands. Journal of Radioanalytical and Nuclear Chemistry, 296(1), 209-214.

Stephanie Cooke. (2009). In Mortal Hands: A Cautionary History of the Nuclear Age Black Inc., p. 168.

The International legal Journal. (2011). The Center for International Legal Affairs, 28 (44).

Vahedi, Gh. (1999). The Principles of the Civil \& Commercial Procedures (Vol. 2, 2nd ed.). Tehran, Mizan \& Dadgostar press, p. 23.

Wittner, L. (2003). The Struggle against the Bomb (Vol. 3). Stanford University Press.

\section{Copyrights}

Copyright for this article is retained by the author(s), with first publication rights granted to the journal.

This is an open-access article distributed under the terms and conditions of the Creative Commons Attribution license (http://creativecommons.org/licenses/by/4.0/). 